\title{
Efficiency of Mergers of Mechanical Engineering Companies in the Czech Republic
}

\author{
Mária Režňáková, Jan Pěta ${ }^{1}$
}

\begin{abstract}
This paper presents the research results in the field of the efficiency of mergers and acquisitions in the mechanical engineering industry of the Czech Republic. The aim of this paper is to determine whether mergers taking place in mechanical engineering are successful, or possibly to identify factors which may be deemed as synergies sources. In our research, the success rate of mergers is identified on the basis of the increasing revenues and operating profit. It has been established that out of mergers completed in 2004 - 2011, success has been achieved in approximately half of them. For this reason, we have focused on identifying the factors which may serve as the reasons for such a difference. The selected indicators of the cost-to-revenue ratio and utilization of fixed assets, investments, and net working capital we analysed before and after the mergers in both groups of successful and unsuccessful mergers. The Mann-Whitney $\mathrm{U}$ test was used to test the results. The research results have demonstrated that synergies are not achieved due to the change in the market power of the merged companied but owing to operational efficiency which is reflected in a drop in labour costs and depreciation to revenues ratios and increasing asset utilization.
\end{abstract}

Key words: Cost efficiency, Investment in fixed assets and net working capital, MannWhitney $\mathrm{U}$ test, Mergers in mechanical engineering, Operating synergies.

\section{JEL Classification: G34}

Received: 30 September/ Accepted: 8 November 2016/Sent for Publication: 9 December 2016

\section{Introduction}

The persistent interest in M\&A research is based on the ambiguity of the results of previous research focusing on investigating the efficiency of corporate mergers. Globally, there has been an increase in the number and value of completed M\&A transactions, with a similar development taking place in the Czech Republic. Last year, in terms of mergers and acquisitions, the world saw the best year in history. According to the EY consultancy company, the total volume of transactions across the globe reached 5 trillion USD. This amount even exceeded the figures recorded in pre-crisis 2007, when the

\footnotetext{
${ }^{1}$ Brno University of Technology, Faculty of Business and Management, Institute of Finances,Kolejní 2906/4,612 00 Brno, reznakova@fbm.vutbr.cz, peta@ fbm.vutbr.cz
}

(C) 2016 by the authors; licensee Review of Economic Perspectives / Národohospodářskýobzor, Masaryk University, Faculty of Economics and Administration, Brno, Czech Republic. This article is an open access article distributed under the terms and conditions of the Creative Commons Attribution 3.0 license, Attribution - Non Commercial - No Derivatives. 
value of transactions reached 4.6 trillion $(\mathrm{EY}, 2016)$. The outlook for this year is similar as well.

M\&A transactions are considered as one of the means of business growth or possibly reorganization, being reflected in increasing the profitability of the invested capital and business value. Mergers result in the concentration of property and economic power into an even smaller number of companies. For this reason, in particular, mergers of companies with a relatively high market share are supervised by authorities for the protection of competition (the so-called anti-monopoly authorities). The completed foreign research indicates that only a part of M\&A transactions will reach positive results in terms of standard efficiency measures (see for instance Waldman and Javidan, 2009; Lovallo and Kahneman, 2003; Pfeffer and Sutton, 2006; Bekie, Bogardus and Oldham, 2001 in Kislingerová, 2007; Sedláček et al., 2013).

\section{Operating synergies and their measurement}

Research into M\&A focuses on three areas, namely research into trends in the M\&A area (how to forecast the M\&A development), reasons for M\&A, and measuring M\&A synergies. This paper presents the results of the ongoing research into the effects of mergers in the manufacturing industry of the Czech Republic. The research focuses on mergers in one sector, carried out between the companies whose shares are not publicly traded. This increases the difficulty in measuring the synergy effect. As the research deals with transactions between companies which are not publicly traded, it is impossible to use an approach based on the change in the share price, but it is necessary to seek other approaches which may lead to the change in the company's value. Furthermore, this procedure may identify the reasons leading to the change in the share price or return on invested capital.

\section{Reasons for business mergers}

According to Mukherjee et al. (2004), the basic reasons for merging companies may be divided into three groups: synergy, diversification, and restructuring. This division is based on a questionnaire survey among managers of companies where a merger took place in 1990 - 2001. In the above-mentioned survey, $90 \%$ of managers identified the operating synergies as the reason for the M\&A transaction; the remaining $10 \%$ represented financial synergies and increasing market power. For the first group, Devos et al. (2009) states that mergers may generate productive efficiencies that result in higher operating profits and/or reduced capital expenses (so-called operating synergies). According to Chatterjee (1986), operating synergies represent a group of limited resources leading to manufacturing and/or administrative efficiency, which may result in economies of scale especially typical for horizontal M\&As. On the other hand, Chatterjee concluded that the financial synergy affects the relative company size: if the company fully uses the possibilities of financial synergies, M\&A profits may exceed those primarily resulting from operating synergies. Financial synergies enable reducing costs of capital (see Chatterjee, 1986).

According to Brealey et al. (2008), merged companies may consolidate management, accounting, financial audit, or development, i.e. savings may occur especially in the area of indirect costs. Similarly, Mellen and Evans (2010) consider, as the main source 
of savings, the consolidation of functions, positions and fixed assets, leading to a decrease in overhead costs.

In the event of vertical mergers, it is also possible to achieve operating savings in the case that the company gains control over the manufacturing process (i.e. merging with the supplier) or obtain distribution channels for the sales of its products (i.e. merging with the customer). This results in the possibility to control the quality of supplied raw materials, as well as increasing profit margins, due to the elimination of at least one level of profit margin existing before the merger.

In addition to operating and financial synergies, Chatterjee (1986) mentions the third category of synergies, i.e. contractual synergies, leading to an increase in the market share. Trautwein (1990) also mentions the third category, labelling it as managerial synergies occurring when the bidder's managers have better planning and monitoring skills. Synergies may in fact be also attained through the transfer of knowledge. Vyas et al. (2012) perceives the managerial synergies as the skills to follow and achieve the plan defined as the goal.

\section{Possibilities of measuring synergies}

A number of realised research projects were based on data of listed companies. In this case, the effect of the merger (synergy) is measured through the change in the share price. Other approaches need to be used in the case of companies whose shares are not publicly traded. The merger effect is usually measured through increasing sales (revenues) or possibly increasing profitability (Griffin and Mahon, 1997, Brouthers et al., 1998) or even net assets (Sedláček et al., 2013).

For the purposes of examining the merger efficiency, Sorensen (2000) and Shim (2011) used financial analysis indicators. They compared the indicator values in companies which completed an M\&A transaction with companies which did not realise any mergers or acquisition. Shim (2011) found out that M\&A had a negative impact on the return on assets and return on equity (ROA, ROE). In the case of ROA, the average drop reached almost $3 \%$, while there was a decline of more than $7 \%$ in the case of the ROE index.

Sedláček et al. (2013) examined the effect of mergers on total assets, accounting value of equity, retained earnings from past years, earnings after taxes, added accounting value, personnel costs, and EBIT. According to their results, the positive effect of mergers to net assets and retained earnings was established only in small and medium-sized companies, being negative in large companies. Conversely, there was an increase in personnel expenses. In the examined period $(2001-2009)$, there was a decline in the indicator of earnings after tax.

In his research, Harford (2005) focused on the factors of synergies arising from operating improvements. Among them, he included the $\mathrm{CF}$ ratio to sales, assets turnover, expenses on research and development, capital expenses, ROA, sales growth, and increase in the staff numbers. He found out that the all the indicators were abnormally increased before the wave of M\&A transaction in the industry. 
According to Devos et al. (2009), operating synergies may be measured through the savings in fixed costs and capital expenditures. Financial synergies may be measured through the savings in income tax (most frequently in the form of an interest tax shield).

\section{Methodology and data}

Our research focused on examining the factors affecting the success of mergers. For this purpose, it was above all necessary to divide the completed mergers into two groups of mergers, the successful and unsuccessful ones. As already mentioned, in the case of companies whose shares are not publicly traded, the merger effect may be measured through a change in sales, profits or possible net assets (Griffin and Mahon, 1997; Brouthers et al., 1998; Sedláček et al., 2013). Subsequently, the comparison included selected indicators of companies in both groups. Due to the fact that operating synergies are the most frequently mentioned reason for mergers, the analysis focused on the indicators measuring the operating efficiency.

\section{Research hypothesis and its verification}

For the purposes of the research, the following research hypothesis was determined: Successful mergers achieve operating synergies reflected in the decline in cost intensity.

On the basis of the results achieved after the merger, the examined transactions were divided into successful and unsuccessful ones, i.e. producing or failing to produce synergies. When dividing transactions, the authors proceeded from the idea of synergy valuation, when the value of synergy consists of an increase in the value of merged companies (see Maŕík, 2011). One of the preconditions for increasing the company's value is the growth of revenues and profit margins which Mařík (2011) ranks among the so-called "value drivers". For this reason, the items of sales and operating profit were used for the purposes of determining the success or failure of the merger. This approach is consistent with previous research into M\&As (see Griffin and Mahon, 1997; Brouthers et al., 1998). The assets value was not used to measure the synergy, as after the merger, the assets consolidation may include the sale of redundant assets.

The successful mergers were deemed those resulting in a higher increase in sales than could be achieved by separate companies while maintaining the same growth rate as before the merger (the so-called stand-alone principle), as well as the mergers resulting in a higher growth of the operating profit while meeting the same criteria. For this purpose, it was necessary to determine the sales forecast for each company for four years (the year of the merger +3 years) on the basis of the average annual sales growth rate achieved before the merger. These values were used to calculate the theoretical value of sales for the merged company $\left(\mathrm{R}^{*}\right)$, i.e. the sum of forecasted revenues for the acquired and acquiring company in the merger year and following three years. Theoretical revenues $\left(\mathrm{R}^{*}\right)$ were compared with actual revenues $(\mathrm{R})$. The following rule was used for the purposes of dividing the merges into successful and unsuccessful groups:

$$
\begin{aligned}
& \mathrm{R}^{*}<\mathrm{R}=>\text { positive effect of the merger, i.e. the merger was successful; } \\
& \mathrm{R}^{*} \geq \mathrm{R}=>\text { negative effect of the merger, i.e. the merge was unsuccessful. }
\end{aligned}
$$


The calculation of the operating profit followed a similar procedure.

The cost intensity was measured through the following indicators:

- The ratio of cost of sales to revenues: this indicator measures whether there is a change in the purchased inputs (costs of materials, energies, and services) to revenues ratios. In the event of a decline, the company would achieve savings due to the increasing market power, i.e. the bargaining power in relation to its trading partners (see Devos et al., 2009; Ficbauer and Režňáková, 2014);

- The ratio of labour costs to revenues: merged companies may consolidate certain functions. As stated by Brealey et al. (2008), it is possible to merge managements, accounting, financial audit, or development;

- Depreciation to revenues ratio: the merged company should consolidate the assets and sell the redundant assets (see Mellen and Evans, 2010). Similarly, it should result in better use of fixed assets and a decline in costs, related to its use, to revenues ratio. However, if the company's assets became obsolete (particularly machinery and equipment), the company would have to invest, which would result in increasing depreciation. For this reason, the assets depreciation rate was also examined.

Due to the fact that according to Devos et al. (2009), operating synergies are also reflected in savings in investments, the analysis examined the indicators of assets turnover, the ratio of net working capital (NWC) to revenues, investment in fixed assets and NWC.

The non-parametric Mann-Whitney U test was used to test the hypothesis. It is an alternative t-test option used in cases of failure to comply with the assumption of standard data distribution (Davies, 2007).

The test calculation is based on the serial numbers of individual variations. When applying it, Bedáňová (2011) recommends the following steps: the first step is to create a file in which all transactions are arranged in the ascending order regardless of which group they come from. The second step is to assign a rank to individual values in the mixed selection. The lowest value is assigned a serial number one, while the highest value is assigned the highest serial number. This encoding will contribute to eliminating extreme values which negatively affect research results. The sample is then used to calculate the sum of ranks within each examined group (labelled $R_{U}$ and $R_{N}$ ). Consequently, it is necessary to calculate the test statistics using the following calculations:

$$
\begin{aligned}
& U_{U}=n_{U} * n_{N}+\frac{n_{U} *\left(n_{U}+1\right)}{2}-R_{U} \\
& U_{N}=n_{U} * n_{N}+\frac{n_{N} *\left(n_{N}+1\right)}{2}-R_{N}
\end{aligned}
$$

Where: $U_{U} \quad$ Test statistics of successful transactions

$U_{N} \quad$ Test statistics of unsuccessful transactions

$n_{U} \quad$ Number of transactions ranked in the successful group

$n_{N} \quad$ Number of transactions ranked in the unsuccessful group

$R_{U} \quad$ Sum of rankings belonging to the values of successful mergers

$R_{N} \quad$ Sum of rankings belonging to the values of unsuccessful mergers 
The lower of the test statistics, i.e. $U=\min \left(U_{U}, U_{N}\right)$ is then used as a test criterion compared with the critical value of the Mann-Whitney test (Bedáňová, 2011). The Statistica software was used for the testing.

\section{Used data}

The following criteria were defined to determine the research sample:

- The merger was completed by companies with the head office in the Czech Republic in $2004-2011$;

- $\quad$ It was the only merger in the period of 7 years (three years before and three years after the merger);

- The financial statements of the acquired (target) and acquiring companies are publicly available.

In order to eliminate the different development in various sectors, the authors focused on examining the efficiency of mergers in one sector, i.e. mechanical engineering (CZNACE 25 and 28). In the specified sectors, 59 mergers met the defined criteria, yet the financial statements were available only for 50 transactions involving 102 companies in total. Half of the mergers took place in the form of the horizontal integration, i.e. merging the entities operating in the same sector, and the other half in the form of the vertical integration, i.e. merging the suppliers and customers.

\section{Results and Discussion}

Diving the mergers into the groups was based on the information on the development of revenues and profits for $2004-2014$ so that each merger is provided with the data for 7 consecutive periods (three years before the merger, three years after the merger and the merger year). The annual trend in the revenues of merged companies was compared both with the situation before the merger (one year before the merger) and with the development in the whole sector in order to ascertain whether the merger's success was influenced by external factors. This comparison was carried out for each merged company covering four years, i.e. the year in which the merger took place and three following years. The trends in profits were analysed in a similar manner, being compared with the situation before the merger. Out of the total number of 50 mergers, 24 transactions (mergers) may be deemed successful and 26 unsuccessful on the basis of the selected criteria.

Compared to the average growth in the sector in the same period, the group of companies included in the successful mergers showed a faster growth of revenues, increasing by $18.8 \%$ in three years. By contrast, the group of companies included in the unsuccessful mergers showed a slower average decline than the decline in the sector in the same period: on average, revenues dropped by $8.1 \%$. From this perspective, even these mergers may be considered relatively successful, but for research purposes, i.e. the identification of operational synergies, they should be regarded as unsuccessful.

On average, the group of successful mergers showed a faster growth of revenues than the revenue growth in the whole sector 2.25 times in four years; in the group of unsuccessful mergers it was 1.58 times on average. In thirteen merged companies, the revenues increased faster every year than the revenues in the whole sector; eight of them 
took place in 2008 , i.e. the year marked by the beginning of the significant decline in demand due to the global financial crisis.

In the group of successful mergers, the operating profit grew by $165 \%$ in three years compared to the year before the transaction; on the contrary, in the group of unsuccessful transactions, the operating profit fell by $47 \%$. For this reason, it is believed that the synergies achieved as a result of merges have the character or operating synergies, attained through cost savings.

\section{Achieving operating synergies through cost savings}

In order to verify whether operating synergies occur as a result of cost savings, the analysis focused on the development of the expense-to-revenues ratios for individual companies before and after the merger was carried out. Table 1 shows the basic statistical values.

Table 1. Statistical values of the expense-to-revenue ratio before and after the merger

\begin{tabular}{|c|c|c|c|c|c|c|c|c|}
\hline \multicolumn{9}{|c|}{ Successful mergers } \\
\hline \multicolumn{2}{|c|}{ Period } & -3 & -2 & -1 & 0 & 1 & 2 & 3 \\
\hline \multirow{3}{*}{$\begin{array}{l}\text { Cost of sales } \\
\text { to Revenues }\end{array}$} & Mean & 0.7307 & 0.6872 & 0.6865 & 0.7092 & 0.7046 & 0.6364 & 0.7148 \\
\hline & Median & 0.6663 & 0.6900 & 0.6893 & 0.6886 & 0.6883 & 0.6246 & 0.6247 \\
\hline & Std. dev. & 0.2691 & 0.2004 & 0.1989 & 0.2047 & 0.2006 & 0.1990 & 0.2248 \\
\hline \multirow{3}{*}{$\begin{array}{l}\text { Labour costs } \\
\text { to Revenues }\end{array}$} & Mean & 0.0985 & 0.1102 & 0.1175 & 0.1188 & 0.1190 & 0.1100 & 0.1153 \\
\hline & Median & 0.1177 & 0.1151 & 0.1279 & 0.1433 & 0.1427 & 0.1342 & 0.1283 \\
\hline & Std. dev. & 0.0901 & 0.1081 & 0.1338 & 0.0905 & 0.0945 & 0.0986 & 0.0968 \\
\hline \multirow{3}{*}{$\begin{array}{l}\text { Depreciation } \\
\text { to Revenues }\end{array}$} & Mean & 0.0439 & 0.0502 & 0.0515 & 0.0442 & 0.0416 & 0.0329 & 0.0285 \\
\hline & Median & 0.0251 & 0.0314 & 0.0378 & 0.0312 & 0.0392 & 0.0323 & 0.0289 \\
\hline & Std. dev. & 0.0299 & 0.0506 & 0.0906 & 0.0363 & 0.0332 & 0.0305 & 0.0378 \\
\hline \multicolumn{9}{|c|}{ Unsuccessful mergers } \\
\hline \multicolumn{2}{|c|}{ Period } & -3 & -2 & -1 & 0 & 1 & 2 & 3 \\
\hline \multirow{3}{*}{$\begin{array}{l}\text { Cost of sales } \\
\text { to Revenues }\end{array}$} & Mean & 0.5792 & 0.6361 & 0.6229 & 0.6146 & 0.6118 & 0.6287 & 0.6225 \\
\hline & Median & 0.5972 & 0.5628 & 0.6066 & 0.5898 & 0.6076 & 0.6302 & 0.5686 \\
\hline & Std. dev. & 0.2898 & 0.2308 & 0.2109 & 0.2009 & 0.1951 & 0.1872 & 0.2159 \\
\hline \multirow{3}{*}{$\begin{array}{l}\text { Labour costs } \\
\text { to Revenues }\end{array}$} & Mean & 0.1073 & 0.1043 & 0.1078 & 0.1205 & 0.1275 & 0.1217 & 0.1294 \\
\hline & Median & 0.1223 & 0.1283 & 0.1342 & 0.1418 & 0.1683 & 0.1564 & 0.1576 \\
\hline & Std. dev. & 0.1294 & 0.1191 & 0.1032 & 0.0865 & 0.0859 & 0.0922 & 0.1026 \\
\hline \multirow{3}{*}{$\begin{array}{l}\text { Depreciation } \\
\text { to Revenues }\end{array}$} & Mean & 0.0382 & 0.0349 & 0.0338 & 0.0315 & 0.0336 & 0.0295 & 0.0324 \\
\hline & Median & 0.0288 & 0.0305 & 0.0299 & 0.0400 & 0.0389 & 0.0368 & 0.0352 \\
\hline & Std. dev. & 0.0441 & 0.0420 & 0.0397 & 0.0419 & 0.0418 & 0.0499 & 0.0501 \\
\hline
\end{tabular}

Source: own research. 
Comparing the average values of the examined indicators in the third year after the merger to the values of the year prior to the merger (t-1) may bring different results in the group of successful and unsuccessful mergers. In the case of successful mergers, there were no savings in the consumption of materials, energy and services; the indicator of the cost of sales to revenues increased by $4.12 \%$, mainly due to an increase in material costs by $20 \%$. This may imply that the completed merger did not result in a change in market power of the merged company, which would be reflected in a decline in input prices. In the case of unsuccessful mergers, the value of this share is approximately the same as before the merger.

Both groups of companies showed an increase in total labour costs of $16.6 \%$ in the case of successful mergers and $10.3 \%$ in the case of unsuccessful mergers. However, the labour costs to sales ratio already show a different trend. In the case of successful mergers, there was a decline in this indicator of $1.87 \%$, i.e. there were relative savings in labour costs. In the group of companies ranked as unsuccessful mergers, there was an increase in the labour costs to revenues ratio by $20 \%$. The main reason consisted in a decline in sales. The share of depreciation to revenues in both groups declined. Yet both groups show a significant difference: in the group of successful mergers, indicator's value dropped by $44.66 \%$, while in the group of unsuccessful mergers, the indicator's value fell by only $4.14 \%$. It may be concluded that the companies ranked among successful mergers consolidated fixed assets, disposing of unnecessary assets.

With the exception of the cost of sales to revenues ratio, the examined indicators support the formulated hypothesis, i.e. there has been a decline in the operating costs to revenues ratios. On the basis of median values of the examined indicators, it may be stated that with the growing number of years following the merger, there is an increase in the difference of the values of expenses-to-revenues ratios in both groups of companies - see Figure 1 .

Figure 1. Difference in the medians of indicators of successful and unsuccessful mergers

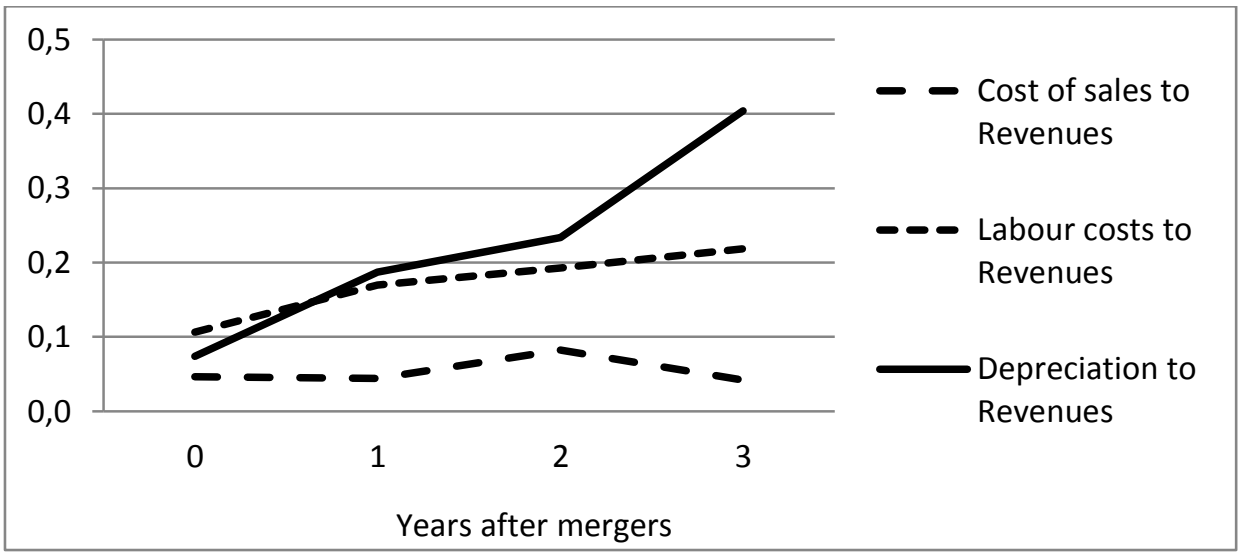

Source: own research 
The chart shows that the difference in the cost of sales to revenues ratios between successful and unsuccessful mergers is insignificant, i.e. it confirms the assumption that there was no change in the market structure and the market power of any of the businesses. The strongest increase in differences was found in the case of the depreciation to revenues ratios. This indicator is higher in the group of unsuccessful mergers. Although differences are obvious, the results were further tested in order to verify the defined research hypothesis. For this purpose, the Mann-Whitney U test was used, determining the precision of the variances of successful and unsuccessful mergers. The results are shown in Table 2 for one year and the summary for all the years is included in Table 3.

Table 2. P-value Mann-Whitney $U$ test of the expense-to-revenues ratios for the third year after the merger

\begin{tabular}{lccccc} 
Variable & $\begin{array}{c}\text { Rank sum } \\
\text { successful }\end{array}$ & $\begin{array}{c}\text { Rank sum } \\
\text { unsuccessful }\end{array}$ & U-stat. & Z-stat. & p-value \\
\hline $\begin{array}{l}\text { Cost of sales } \\
\text { to Revenues }\end{array}$ & 582.0000 & 693.0000 & 282.0000 & -0.57284 & 0.56675 \\
$\begin{array}{l}\text { Labour costs } \\
\text { to Revenues }\end{array}$ & 453.0000 & 822.0000 & 153.0000 & -3.07781 & 0.00209 \\
$\begin{array}{l}\text { Depreciation } \\
\text { to Revenues }\end{array}$ & 487.0000 & 788.0000 & 187.0000 & -2.41759 & 0.01562 \\
\hline
\end{tabular}

Source: own research.

Table 3. P-value Mann-Whitney $U$ test of the expense-to-revenues ratios

\begin{tabular}{lccccccc} 
& -3 & -2 & -1 & 0 & 1 & 2 & 3 \\
\hline $\begin{array}{l}\text { Cost of sales } \\
\text { to Revenues }\end{array}$ & 0.3364 & 0.0725 & 0.4316 & 0.3316 & 0.5668 & 0.9149 & 0.5668 \\
$\begin{array}{l}\text { Labour costs } \\
\text { to Revenues }\end{array}$ & 0.9923 & 0.8842 & 0.8082 & 0.0249 & 0.0368 & 0.0057 & 0.0021 \\
$\begin{array}{l}\text { Depreciation } \\
\text { to Revenues }\end{array}$ & 0.6622 & 0.5472 & 0.2440 & 0.0080 & 0.0558 & 0.0822 & 0.0156 \\
\hline
\end{tabular}

Source: own research.

On the basis of the values of the test characteristics, it may be stated that in the case of the cost of sales to revenues ratios, there is no statistically significant difference between the groups. The values of the indicator of labour costs to revenues differ significantly in all examined years after the mergers. The difference between the two groups increases over time. There was a statistically significant difference in the depreciation to revenues ratio in the first and third year after completing the merger. Although the difference in median values of the indicators in the second year after the merger is not statistically significant, the p-value is not high (0.0822). The results also show that none of the examined indicators before the merger acquires a statistically significant difference. Therefore, the change in the values of these indicators after the merger may actu- 
ally be considered as the effect of the merger, i.e. a manifestation of operating synergies achieved through economies of scale.

\section{Achieving operating synergies through reductions in investments}

Reductions in investments (see Devos et al., 2009) represent one of the sources of creating operating synergies. For this reason, we focused on the analysis of the development of the fixed assets and investments in the net working capital.

As already stated, the depreciation to revenues ratios dropped in both groups, yet the development was different. One of the reasons could consist in the fact that companies in the group of successful mergers consolidated fixed assets, disposing of unnecessary assets. The second reason could consist in higher investment in fixed assets in the group of unsuccessful mergers. These assumptions were further analysed - see Table 4.

Table 4. Selected characteristics of fixed assets and asset utilisation

Successful mergers

\begin{tabular}{|c|c|c|c|c|c|c|c|}
\hline Period & -3 & -2 & -1 & 0 & 1 & 2 & 3 \\
\hline $\begin{array}{l}\text { Net book value of sold fixed assets } \\
\text { (FA) in millions CZK }\end{array}$ & 37.8 & 101.6 & 125.7 & 142.4 & 32.2 & 9.1 & 19.4 \\
\hline $\begin{array}{l}\text { Share of net book value of sold FA } \\
\text { in the net book value of FA }(\%)\end{array}$ & 0.37 & 1.03 & 1.31 & 1.55 & 0.36 & 0.10 & 0.22 \\
\hline Investment rate in fixed assets (\%) & $x$ & 7.53 & 7.98 & 5.53 & 5.93 & 9.62 & 4.97 \\
\hline Depreciation rate of fixed assets (\%) & 33.93 & 32.22 & 39.16 & 41.82 & 45.03 & 46.15 & 48.20 \\
\hline Assets turnover & 1.136 & 1.087 & 0.947 & 0.971 & 0.974 & 1.036 & 1.058 \\
\hline \multicolumn{8}{|c|}{ Unsuccessful mergers } \\
\hline Period & -3 & -2 & -1 & 0 & 1 & 2 & 3 \\
\hline $\begin{array}{l}\text { Net book value of sold fixed assets } \\
\text { (FA) in millions CZK }\end{array}$ & 21.4 & 39.0 & 52.7 & 16.7 & 21.0 & 64.2 & 30.6 \\
\hline $\begin{array}{l}\text { Share of net book value of sold FA } \\
\text { in the net book value of FA }(\%)\end{array}$ & 0.67 & 1.10 & 1.45 & 0.60 & 0.76 & 1.93 & 0.81 \\
\hline Investment rate in fixed assets (\%) & $\mathrm{x}$ & 24.50 & 15.22 & -13.10 & 11.97 & 35.24 & 25.79 \\
\hline Depreciation rate of fixed assets (\%) & 42.07 & 42.45 & 43.31 & 49.60 & 52.50 & 50.91 & 46.99 \\
\hline Assets turnover & 1.169 & 1.255 & 1.307 & 1.432 & 1.388 & 1.302 & 1.263 \\
\hline
\end{tabular}

Source: own research.

The average value of the assets turnover increased by $11.75 \%$ in the case of successful mergers, while decreasing by $3.4 \%$ in the group of unsuccessful mergers. This could be due to different trends in revenues (growing by $19 \%$ in the group of successful mergers and declining by $8 \%$ in the group of unsuccessful transactions) or possibly due to higher investment in the group of unsuccessful mergers owing to the worse age structure of fixed assets. For this reason, the further analysis included the indicators of the 
depreciation rate of fixed assets, characterising the sale of fixed assets, which affects the depreciation rate as well. In the year of the merger, the share of depreciation of fixed assets reached $41.8 \%$ for the successful transactions and $49.6 \%$ for the unsuccessful mergers, i.e. the fixed assets were more depreciated. The ratios reversed at the end of the examined period. Similarly, the values of the indicator of the investment rate in fixed assets, representing the investment in a given year to the initial value of fixed assets, are higher in the group of unsuccessful mergers. This implies that companies engaged in the unsuccessful merger actually invested in fixed assets. However, part of the fixed assets was also sold, i.e. they probably needed cash or investments were not chosen appropriately. The value of sales of fixed assets was higher in this group than in the group of successful mergers.

In addition to investments in fixed assets, the analysis also focused on the investment in NWC, also affecting the degree of asset utilisation. The group of companies engaged in a successful merger showed an increase in the ratio of NWC to revenues of $14.6 \%$. The increase was mainly due to investments in stocks with a considerable decline in the maturity of short-term liabilities. This finding supports the conclusion that the merger did not change the market power of the merged company. At the same time, it implies that the merged companies have additional reserves for reductions in inventory management. On the other hand, the group of companies engaged in the unsuccessful mergers saw a decline in the ratio of NWC to revenues of $35.2 \%$. These reductions were achieved in the area of inventory management.

The observed differences were subject to the statistical significance test (see Table 5).

Table 5. P-value Mann-Whitney $U$ test of investments and assets utilisation

\begin{tabular}{lccccccc} 
& -3 & -2 & -1 & 0 & 1 & 2 & 3 \\
\hline Investments in fixed assets & $\mathrm{x}$ & 0,0424 & 0.3666 & 0.1374 & 0.7487 & 0.7122 & 0.5029 \\
Investments in NWC & $\mathrm{x}$ & 0.9768 & 0.3983 & 0.4785 & 0.4547 & 0.8536 & 0.4431 \\
Assets turnover & 0.8842 & 0.9923 & 0.4906 & 0.8689 & 0.2249 & 0.0275 & 0.0351
\end{tabular}

Source: own research.

In the case of the assets turnover indicator, the difference in median values is statistically significant only in the second and third year following the merger, i.e. the growing distance from the merger increases the difference in the assets utilisation. On the other hand, there is no statistically significant difference between the groups in the investments in fixed assets or in the net working capital. This implies that the difference in assets utilisation stems from a difference in revenues development. On the other hand, a statistically significant difference was identified two years before the merger in the case of investments in fixed assets, which may be considered a crucial finding for the success of the merger. 


\section{Conclusions}

Within the examined sample of 50 mergers of mechanical engineering companies in the Czech Republic, which took place in 2004 - 2011, it was revealed that in three years following the merger, $48 \%$ of the transactions saw an increase in revenues and profits. Within three years following the merger, the group of successful mergers saw an increase in the revenues of $19 \%$ compared to the year before the transaction. On the contrary, there was a decline in the revenues of more than $8 \%$ in the group of unsuccessful mergers. Within three years, operating profits of the group of successful mergers rose by $165 \%$ compared to the year before the transaction, whereas the group of unsuccessful mergers saw a decline in operating profits of $47 \%$.

Most authors consider operating synergies the most important reasons for merges of companies. For this reason, the analysis focused on the development of the cost-torevenue ratio, investments and asset utilisation. The results showed that the biggest difference between the examined groups was found in profit development. On the one hand, this growth was achieved through revenue growth, as well as savings in labour costs and depreciation. The statistical significance test showed that there was a statistically significant difference in mean values of indicators of labour costs to revenues and depreciation to revenues. Therefore, ten companies were able to save on investments in renewal of assets. This finding was confirmed, yet the difference was not statistically significant.

On the other hand, the analysis did not confirm the assumption that successful mergers also achieve savings in the cost of materials, energies and services. This may imply that the merger did not result in significant increase of market power of combined firms. It is consistent with prior studies. They find little evidence of anticompetitive, collusive behaviour.

It is impossible to identify the difference in the mean values of cost-to-revenue ratios and turnover between the successful and unsuccessful transactions in the time before the mergers. The achieved savings may thus unambiguously be considered as the positive effect of the mergers. The assumption on achieving operating synergies of successful mergers by improving resource utilization and cost savings from operating improvements has thus been confirmed.

However, prior to the merger, there was a different development in investments in fixed assets (already two years before the merger). It may thus be assumed that the companies engaged in successful mergers prepared for a merger in advance.

Funding: The paper is an outcome of the research project "Selected Issues of Financial Management in the International Environment", funded by the Internal Grant Agency of the Brno University of Technology, registration number FP-S-15-2877.

Disclosure statement: No potential conflict of interest was reported by the authors. 


\section{References}

BEDÁŇOVÁ, I. (2011). Neparametrické testy. Biostatistika [online]. Brno: Veterinární a farmaceutická univerzita Brno [cit. 2016-05-18]. Available at: http://cit.vfu.cz/statpotr/POTR/Teorie/Predn4/MannWhit.htm

BREALEY, R. A., S. C. MYERS and F ALLEN. (2008). Principles of corporate finance. 9th ed. [international edition]. Boston, Mass: McGraw-Hill. ISBN 978-0071266-758.

BROUTHERS, K. D., P. VAN HASTENBURG and J. VAN DEN VEN. (1998). If most mergers fail why are they so popular? Long Range Planning. 31(3), 347-353. DOI: 10.1016/S0024-6301(98)80002-2

DAVIES, M. B. (2007). Doing a successful research project: using qualitative or quantitative methods. Houndmills, Basingstoke, Hampshire ; New York: Palgrave Macmillan, xiv, 274 s. : il. ISBN 978-1-4039-9379-3.

DEVOS, E., P.-R. KADAPAKKAM and S. KRISHNAMURTHY. (2009). How Do Mergers Create Value? A Comparison of Taxes, Market Power, and Efficiency Improvements as Explanations for Synergies. Review of Financial Studies. 22(3), 11791211. DOI: $\underline{10.1177 / 000765039703600102}$

EY. (2016). M\&A Barometr 2015 Česká republika [online]. In: . [cit. 2016-07-07]. Available at: http://www.ey.com/Publication/vwLUAssets/2016-MA-Barometer-CZ2015/\$FILE/MA_Barometer_CR_2016.pdf

FICBAUER, D. and M. REŽŇÁKOVÁ. (2014). Holding Company and Its Performance. Acta Universitatis Agriculturae et Silviculturae Mendelianae Brunensis. 62(2), 329-337. DOI: $10.11118 /$ actaun201462020329

GRIFFIN, J. J. and J. F. MAHON. (1997). The Corporate Social Performance and Corporate Financial Performance Debate: Twenty-Five Years of Incomparable Research. Business. 36(1), 5-31. DOI: 10.1177/000765039703600102

HARFORD, J. (2005). What drives merger waves? Journal of Financial Economics. 77(3), 529-560. DOI: http://dx.doi.org/10.1016/j.jfineco.2004.05.004.

CHATTERJEE, S. (1986). Types of synergy and economic value: The impact of acquisitions on merging and rival firms. Strategic Management Journal. 7(2), 119-139. DOI: $\underline{10.1002 / \mathrm{smj} .4250070203}$

KISLINGEROVÁ, E. (2007). Manažerské finance. 2. přeprac. a rozš. vyd. Praha: C. H. Beck, 745 s. Beckova edice ekonomie. ISBN 978-80-7179-903-0.

LOVALLO, D. and D. KAHNEMAN. (2003). Delusions of success. How optimism undermines executives' decisions. Harvard business review. 81(7), 8. ISSN 0017-8012.

MAŘÍK, M. (2011). Metody oceňováni podniku: proces oceněni - základní metody a postupy. 3. upr. a rozš. vyd. Praha: Ekopress, 494 s. ISBN 978-80-86929-67-5.

MELLEN, Ch. M. and F. C. EVENS. (2010). Valuation for M\&A: building value in private companies. 2nd ed. Hoboken, N.J.: Wiley, 383 s. ISBN 978-0-470-60441-0. 
MUKHERJEE, T. K., H. KIYMAZ and H. K. BAKE. (2004). Merger Motives and Target Valuation: A Survey of Evidence from CFOs. Journal of Applied Finance. 14(2), 7-24.

PFEFFER, J. and R. I. SUTTON. (2006). EVIDENCE-BASED MANAGEMENT. Harvard Business Review. 84(1), 9. ISSN 0017-8012.

SEDLÁČEK, J., VALOUCH, P. and A. KONEČNÝ. (2013). Synergic motives and economic success of mergers of Czech companies. Acta Universitatis Agriculturae et Silviculturae Mendelianae Brunensis. 61(7), 2721-2727. DOI: 10.1007/s10693-010$\underline{\text { 0094-3 }}$

SHIM, J. (2011). Mergers \& Acquisitions, Diversification and Performance in the U.S. Property-Liability Insurance Industry. Journal of Financial Services Research. 39(3), 119-144. DOI: $\underline{10.1007 / \mathrm{s} 10693-010-0094-3}$

SORENSEN, D. E. (2000). Characteristics of merging firms. Journal of Economics and Business. 52(5), 423-433. DOI: http://dx.doi.org/10.1016/s0148-6195(00)00028-x.

TRAUTWEIN, F. (1990). Merger motives and merger prescriptions. Strategic Management Journal. 11(4), 283-295. DOI: 10.1057/9781137278074.0011

VYAS, V., K. NARAYANAN and A. RAMANATHAN. (2012). Determinants of Mergers and Acquisitions in Indian Pharmaceutical Industry. Eurosian Journal of Business and Economics. 5(9), 79-102.

WALDMAN, D. A. and M. JAVIDAN. (2009). Alternative forms of charismatic leadership in the integration of mergers and acquisitions. The Leadership Quarterly. 20(2), 130-142. DOI: 10.1016/j.leaqua.2009.01.008 